EGF receptor levels in adult rat liver. The present study supports these observations and shows that the developing mouse responds to thyroid hormone with increased levels of endogenous EGF receptors in a known EGF target organ, the skin. Thus, one mechanism for modulation of developmental events by thyroid hormones is the modulation of growth factor receptors.

\section{REFERENCES}

1. Angeletti PU, Salvi ML, Ohesanow RL, Cohen S 1964 Azion del "Epidermal Growth Factor" sulla sintesi di acidi nucleici e proteine dell' epitelio cutaneo. Experientia 20:146-148

2. Bynny RL, Orth DN, Cohen S, Doyne ES 1974 Epidermal growth factor: effects of androgens and adrenergic agents. Endocrinology 95:776-782

3. Carpenter $G$ (1980) Epidermal growth factor is a major growth-promoting agent in human milk. Science 210:198-199

4. Carpenter G, Lembach KJ, Morrison MM, Cohen S 1975 Characterization of the binding of $\mathrm{I}^{125}$-labeled epidermal growth factor to human fibroblasts. $J$ Biol Chem 250:4297-4304

5. Clarke RM, Hardy RN 1969 An analysis of cessation of uptake of macromolecular substances by the intestine of the young rat ("closure"). J Physiol Lond 204:127-134

6. Clarke RM, Hardy RN 1969 The use of polyvinyl pyrrolidone K.60 in the quantitative asessment of the uptake of macromolecular substances by the intestine of the young rat. J Physiol Lond 204:113-125

7. Cohen S, Taylor JM 1974 Epidermal growth factor: chemical and biological characterization. Rec Prog Horm Res 30:533-550

8. D'Ercole AJ, Applewhite GT, Underwood LE 1980 Evidence that somatomedin is synthesized by multiple tissues in the fetus. Dev Biol 75:315-328

9. Epstein EH Jr, Munderloh NJ, Fukyyama K 1979 Dithiothreitol separation of newborn rodent dermis and epidermis. J Invest Dermatol 73:207-210

10. Fleck A, Munro HN 1962 The precision of ultraviolet absorption measurements in the Schmidt-Thannhauser procedure for nucleic acid estimation. Biochem Biophys Acta 551:571-583

11. Frati L, Conci G, Sbaraglia G, Venza Teti D, Corelli I 1976 Levels of epidermal growth factor in mice tissues measured by a specific radioreceptor assay. Life Sci 18:905-912

12. Giles KN, Myers A 1965 An improved diphenylamine method for the estimation of deoxyribonucleic acid. Nature 206:93
13. Green MR, Basketter DA, Couchman JR, Rees DA 1983 Distribution and number of epidermal growth factor receptors in skin is related to epithelial cell growth. Dev Biol 10:506-512

14. Hoath SB, Lakshmanan J, Fisher DA 1983 Differential hormone response of epidermal growth factor concentration in the developing mouse: synergism of triiodothyronine and dexamethasone in epidermal maturation. Life Sci 32:2709-2716

15. Hoath SB, Lakshmanan J, Scott SM, Fisher DA 1983 Effect of thyroid hormones on epidermal growth factor concentration in neonatal mouse skin. Endocrinology 112:308-314

16. Hock RA, Hollenberg MD 1980 Characterization of the receptor for epidermal growth factor-urogastrone in human placenta membranes. J Biol Chem 255:10731-10736

17. Karnofsky D, Cronkite EP 1939 Effect of thyroxine on eruption of teeth in newborn rats. Proc Soc Exp Biol 40:568-570

18. Khamsi F, Eayrs JT 1966 A study of the effects of thyroid hormones on growth and development. Growth 30:143-156

19. Lowry OH, Rosebrough NJ, Farr AL, Randall RJ 1951 Protein measurement with the Folin phenol reagent. J Biol Chem 193:265-275

20. Mukku VR 1984 Regulation of epidermal growth factor receptor levels by thyroid hormone. J Biol Chem 259:6543-6547

21. O'Keefe F, Hollenberg MD, Cuatrecasas P 1974 Epidermal growth factorcharacteristics of specific binding in membranes from liver, placenta and other target tissues. Arch Biochem Biophys 164:518-526

22. Peterson GL 1977 A simplification of the protein assay method of Lowry et al. which is more generally applicable. Anal Biochem 83:346-356

23. Savage CR Jr, Cohen S 1972 Epidermal growth factor and new derivative Rapid isolation procedures and biological and chemical characterization. $\mathbf{J}$ Biol Chem 247:7609

24. Scatchard G 1949 The attraction of protein for small molecules and ions. Ann NY Acad Sci 51:660-672

25. Shing YW, Klagsbrun M 1984 Human and bovine milk contain different sets of growth factors. Endocrinology 115:273-282

26. Starkey RH Orth DN 1977 Radioimmunoassay of human epidermal growth factor (urogastrone). J Clin Endocrinol Metab 45:1144-1153

27. Thornburg W, Matrisian L, Magun B, Koldovsky O 1984 Gastrointestinal absorption of epidermal growth factor in suckling rat. Am $\mathrm{J}$ Physiol 246:G80-G85

28. Walker DG 1957 An assay of the skeletogenic effect of L-triiodothyronine and its acetic acid analogue in immature rats. Johns Hopkins Hosp Bull 101:101114

\title{
Intrauterine Growth-Retarded Rat Pups Show Increased Susceptibility to Pulmonary $\mathrm{O}_{2}$ Toxicity
}

\author{
LEE FRANK, PAMELA L. LEWIS, AND TERESA GARCIA-PONS \\ Pulmonary Research Division and Oak Asthma Research and Treatment Facility, University of Miami School of \\ Medicine, Miami, Florida 33101
}

\begin{abstract}
We used a nutritional deprivation model to produce intrauterine growth-retarded (IGR) rat pups (birth weight $=\sim 75 \%$ of normal). The IGR newborns evidenced a marked reduction in tolerance to $>95 \% \mathrm{O}_{2}$ exposure: 10 day survival $=10 / 47(21 \%)$ versus $18 / 36(50 \%)$ for control pups, and $\mathrm{LT}_{50}=7.2$ days versus 10 days for controls $(p$ $<0.01)$. Various lung parameters at birth and during $\mathrm{O}_{2}$
\end{abstract}

Received July 20, 1984; accepted October 24, 1984.

Reprint requests: Dr. Lee Frank, Pulmonary Research R120, University of Miami, School of Medicine, P.O. Box 016960, Miami, FL 33101.

Supported by NIH Grant HL 26029 and NHLBI Research Career Development Award HL01230. exposure were examined to try to define why prenatal undernutrition should compromise the survival of IGR rats in hyperoxia. We found decreased lung glutathione peroxidase and glucose-6-phosphate dehydrogenase activity (with normal superoxide dismutase and catalase levels) in the IGRs at birth; decreased lung disaturated phosphatidylcholine content (even more markedly decreased in 1day premature pups); and decreased lung surface area/body weight. These factors and other features of newborn IGRs reported in the literature may help to explain how prenatal undernutrition compromises postnatal tolerance to prolonged high- $\mathrm{O}_{2}$ exposure. (Pediatr Res 19: 281-286, 1985) 


\section{Abbreviations}

IGR, intrauterine growth retardation SOD, superoxide dismutase CAT, catalase GP, glutathione peroxidase

G-6-PD, glucose-6-phosphate dehydrogenase DSPC, disaturated phosphatidylcholine

PL, phospholipid

ISA, internal surface area

$V_{L}$, lung volume

$\mathbf{L}_{\mathbf{m}}$, linear intercept

Small for gestational age or IGR infants are believed to experience periods of in utero undernutrition (produced by a diversity of pathological conditions), and due to perinatal difficulties may require prolonged $\mathrm{O}_{2}$ therapy after birth $(1,2)$. Acute and chronic lung damage resulting from prolonged treatment with high concentrations of $\mathrm{O}_{2}$ is a frequently encountered problem in sick newborns $(3,4)$. The ability of newborn rat pups to tolerate prolonged exposure to high levels of $\mathrm{O}_{2}$ is seriously compromised by postnatal undernutrition (5). We wondered if IGR, or prenatal undernutrition, would also have an effect on the newborn's ability to tolerate hyperoxic challenge. We describe herein studies which indicate that nutritional deprivation in utero results in significantly compromised neonatal tolerance to hyperoxia. We also discuss the results of studies which were done to try to help us understand why prenatal growth retardation should detrimentally affect postnatal ability to resist pulmonary $\mathrm{O}_{2}$ toxicity.

\section{METHODS}

Pregnant animals. Adult Sprague-Dawley albino female rats were originally obtained from Charles River Laboratories, Wilmington, MA and were maintained in our rat breeding rooms at the University of Miami Animal Care Facility. Timed-pregnancy rats were obtained by housing (2) female rats with a male rat overnight, and using a sperm-positive vaginal smear the next morning to indicate pregnancy. The midpoint of the cohabitation period was considered as the time of conception. The pregnant rats were then housed separately and kept on water ad libitum and standard Laboratory Chow (Rodent Lab Chow 5001, Ralston-Purina, St. Louis, MO) either ad libitum (normally nourished controls) or from the midpoint of pregnancy (day 11) onward were restricted to $\sim 25 \%$ of the dietary intake of the control pregnant rats (IGR group).

Newborn rat pups and exposures to hyperoxia. Within $6 \mathrm{~h}$ of birth the normal and IGR pups from all the litters used were pooled together briefly in a specially constructed "rat pup incubator" consisting of a cloth-lined wire box atop a gently rocking shaker bath unit (Dubnoff Metabolic Shaking Bath, Precision Scientific, Chicago, IL). The temperature in the incubator was maintained at $33-35^{\circ} \mathrm{C}$ with heat lamps. The pooled pups were then randomly redistributed to the individually caged dams in litter sizes of 10-11 pups/dam. (Only dams which had been on an ad libitum feeding protocol during pregnancy were used.) Half of the litters with their dams were placed in hyperoxic exposure chambers $\left(>95 \% \mathrm{O}_{2}\right)$, and half were kept in room air chambers. The rat pups were in the chambers continuously for 7-10 days except for a 10- to 15-min period daily when the pups were removed for weighing and the dams were switched between $\mathrm{O}_{2}$ and air litters. This was necessary to avoid pulmonary $\mathrm{O}_{2}$ toxicity in the nursing mother rats. Dams were carefully observed, and any dam who appeared to be rejecting a litter was replaced with an extra nursing dam kept especially for this purpose. (This was only necessary once; rat dams are very good "foster mothers").

Exposures were conducted in $3.5 \mathrm{ft}^{3}$ chambers constructed from modified clear-plastic nursery isolettes (model 86, Air Shields-Narco, Hatboro, PA). The chamber conditions were carefully monitored throughout the exposures $\left(96-98 \% \quad \mathrm{O}_{2}-\right.$ Beckmann oxygen analyzer, model $\mathrm{OM}-11 ;<0.5 \% \mathrm{CO}_{2}-$ Beckmann medical gas analyzer, model LB- $2 ; 23-26^{\circ} \mathrm{C}$, in-chamber thermometers; 50-70\% humidity, in-chamber hygrometers).

Lung preparations. The control and IGR pups were monitored daily for survival. After 5 days in $>95 \% \mathrm{O}_{2}$ (or $21 \% \mathrm{O}_{2}$ ) some of the pups were removed and killed by intraperitoneal injection of pentobarbital sodium followed by exsanguination. In some pups the lungs were immediately cleared of blood by perfusion with cold isotonic buffer $(0.1 \mathrm{M}$ potassium phosphate, $0.15 \mathrm{M} \mathrm{KCl}$, $\mathrm{pH}$ 7.4) through the pulmonary artery, with the left atrial appendage removed for drainage. These lungs were then weighed and homogenized in cold hypotonic buffer $(0.005 \mathrm{M}$ potassium phosphate, $\mathrm{pH} 7.8)(25: 1, \mathrm{v} / \mathrm{w})$ for biochemical analyses described below. The lungs of other rat pups were formalin-fixed in situ for microscopic study. Ten percent buffered formalin was infused via a tracheal cannula at a constant pressure of $20 \mathrm{~cm} \mathrm{H}_{2} \mathrm{O}$ to inflate the lungs. After fixation in the inflated state for $48 \mathrm{~h}$, similarly oriented sections of each lobe were prepared for hematoxylin and eosin staining and subsequent microscopic examination (see below). Similar lung preparations were carried out in newborn pups from both groups.

Biochemical analyses. Fresh homogenates from the perfused lungs were assayed for superoxide dismutase (SOD) activity by the ferricytochrome $c$ method (6) and for lung DNA (7), RNA (8), and protein (9) content, using purified DNA, RNA, and bovine serum albumin as standards (Sigma Chemical Co., St. Louis, MO). Analyses for lung catalase (CAT) (10), GP (11), and G-6-PD (12) activity were done on the $15,000 \times \mathrm{g} 10 \mathrm{~min}$ homogenate supernatant fluid stored frozen overnight.

Lung PL and DSPC assays utilized initial lipid extraction of lung homogenates by the method of Bligh and Dyer (13). The extracts were dried under nitrogen, reconstituted with chloroform:methanol (2:1), and assayed for total lipid phosphorus following the method of Morrison (14). A portion of the dried lipid extract in chloroform:methanol $(2: 1)$ was used to isolate DSPC by the method described by Mason et al. (15). An internal standard of $\left[{ }^{14} \mathrm{C}\right]-\mathrm{DSPC}$ was added before extraction to estimate and correct for losses during the isolation of DSPC (New England Nuclear, Boston, MA).

Microscopic studies. Microscopic sections were evaluated by light microscopy at $450 \times$ magnification. An eye-piece with a simple square-grid pattern was used (square grid with five horizontal lines and 25 intercept bars, model CPLW $10 \times / 18$ eyepiece, Zeiss Optical, West Germany). A minimum of 30 lung
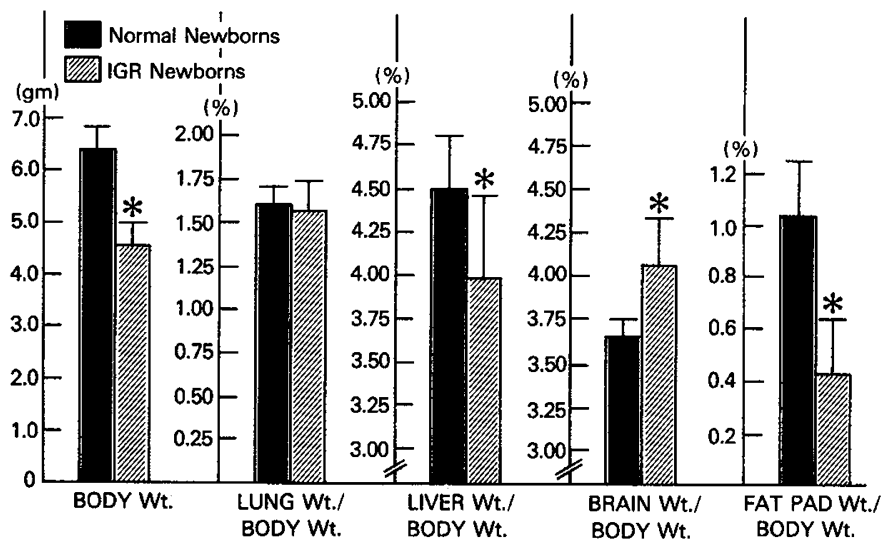

Fig. 1. Body weights and organ weights/body weight in newborn rat pups. The effect of prenatal undernutrition is shown in comparison of gravimetric parameters between IGR newborns and newborns from normally nourished pregnant rats. Values are means $(n=30-36)$ with 1 SD bar, ${ }^{*} p<0.01$ between newborn groups. 


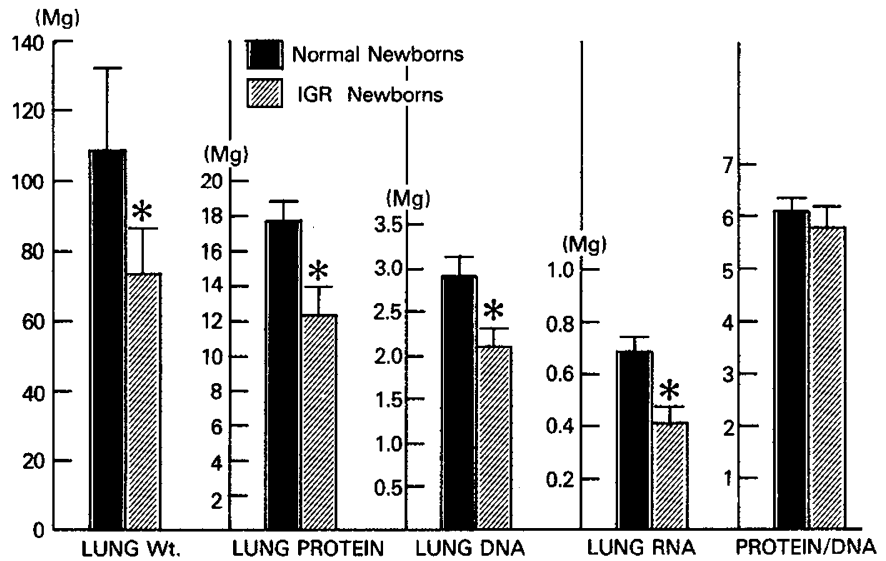

Fig. 2. Lung biochemical parameters in newborn rat pups. The effect of prenatal undernutrition is shown in comparison of lung protein, DNA, RNA contents, and protein/DNA ratio (related to lung cell size) between IGR newborns and newborns from normally nourished pregnant rats. Values are means $(n=12)$ with $1 \mathrm{SD}$ bar; ${ }^{*} p<0.01$ between newborn groups.

fields from each of three different lung sections (left lung, right middle lobe, and right lower lobe) per animal were examined, with four to six animals used per group. To calculate the mean $\mathrm{L}_{\mathrm{m}}$ (representing the average distance between alveolar walls) we used the formula $L_{m}=n \cdot L / \xi i$, where $n$ is the number of lines counted, $\mathrm{L}$ is the length of the line, and $\xi \mathrm{i}$ is the sum of alveolar intercepts (16). To calculate the ISA we used the formula ISA = $4 \cdot V_{L} / L_{m}(16)$, where $V_{L}$ is the postfixation lung volume by water displacement (17). All of the coded slides were examined by two of the authors.

Statistical analysis. For comparisons of differences between the control and IGR rat pups, Student's unpaired $t$ analysis was done; $p$ values of $<0.05$ were considered statistically significant. Differences in survival rates were determined at the $p<0.05$ level by $\chi^{2}$ testing (18). The Litchfield-Wilcoxon graphic analysis test (19) was used for calculation of $\mathrm{LT}_{50}$ values (lethal time for $50 \%$ of the experimental animals in each group), $95 \%$ confidence limits, and for determining significant differences in the $\mathrm{LT}_{50}$ values at the $p<0.05$ level.

\section{RESULTS}

The experimental model for producing IGR newborn rat pups was quite replicable. There were $<10 \%$ stillborn fetuses found in the large number of pregnant rats put on the $25 \%$ food intake diet. Litter size averaged 10.5 versus 11.2 pups/litter in the controls. Figure 1 indicates that the average body weights of IGR pups at birth were $\sim 25-30 \%$ lower than for normal pups. While absolute organ weights (lung, liver, brain, dorsal fat pad) were all significantly lower in the IGR pups, when expressed as the ratio of organ weight/body weight (Fig. 1) the lung weights were equivalent in the two groups of pups, while liver and especially fat pad weights were decreased but brain weight/body weight was increased in the IGRs.

Figure 2 shows that the lungs of the IGR pups had significantly depressed protein, DNA, and RNA content compared to the normal pups. However, when these were calculated on a per lung weight basis, lung protein/, lung DNA/, and lung RNA/g lung were similar in both groups, as were the protein/DNA ratios in the IGRs $(5.80 \pm 0.31)$ and control pup lungs $(6.02 \pm 0.29)$ which suggests that the IGR lungs had fewer cells, but cells of equal size to those of the normal newborn animals.

Figure 3 indicates that prenatal undernutrition did not impair the postnatal growth of the IGR pups nurtured by dietary replete dams. These pups grew as well as the normal pups maintained in air or exposed to hyperoxia, as seen by the parallel growth curves.

Figure 4 shows the comparative survival rates of the two groups of pups simultaneously exposed to hyperoxia. The IGR pups tolerated high $\mathrm{O}_{2}$ more poorly than the normal pups, with significantly depressed survival rates at all exposure times between days 6 and 10 . The $\mathrm{LT}_{50}$ (with $95 \%$ confidence limits) was reduced from 10 days $(8.68-11.52)$ in the normal rats to 7.2 days $(6.21-8.35)$ in the IGR group $(p<0.05)$. Only $21 \%$ of the IGRs survived 10 days in $>95 \% \mathrm{O}_{2}$ compared to $50 \%$ of the control neonatal pups $(p<0.005)$.

To look for some biochemical/physiological/morphological explanation for the increased susceptibility of the IGRs to $\mathrm{O}_{2}$ toxicity, we assayed the lung antioxidant enzymes, lung surfactant, and lung morphometry in the two groups at birth. The data in Table 1 indicates no difference in the activities of the antioxidant enzymes SOD and CAT, but significantly reduced GP and

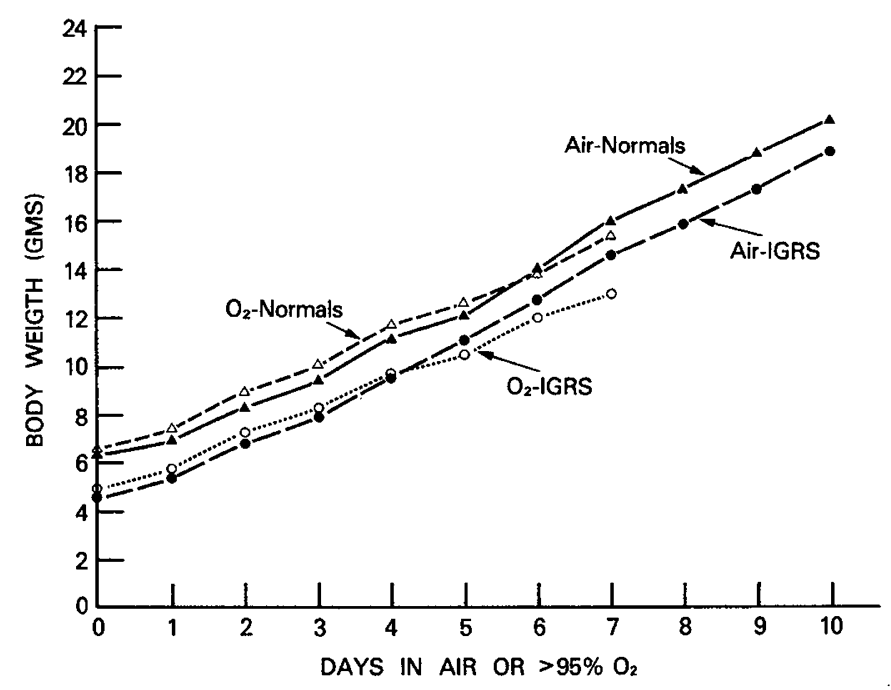

Fig. 3. Growth curves of newborn rat pups. Body weight changes in IGR pups and pups from normally nourished pregnant rats are shown, both for groups maintained in room air environment and for those exposed to $>95 \% \mathrm{O}_{2}$ from the time of birth. All pups after birth were nurtured by normally nourished dams. Values represent composite data from $\sim 60$ rat pups per group (for the first 7 days of life).

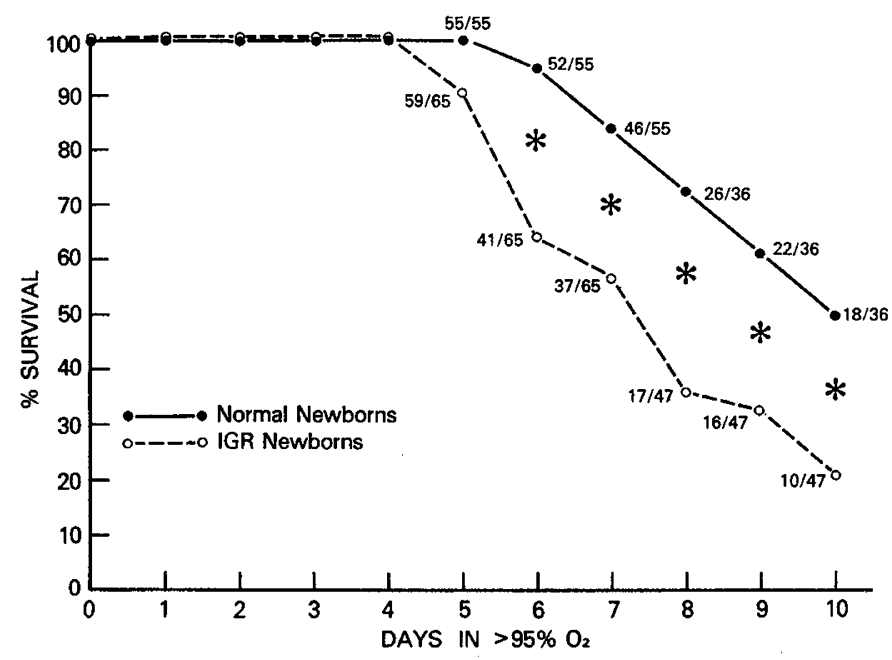

Fig. 4. Survival of normal and IGR rat pups in hyperoxia. Comparative 10-day survival rates in $>95 \% \mathrm{O}_{2}$ for newborn IGR pups and pups from normally nourished pregnant rats. Numbers are no. surviving/no. exposed to $\mathrm{O}_{2}{ }^{*} p<0.01$ for comparative survival values between groups, days $6-10$, by $\chi^{2}$ testing. 
G-6-PD in the lungs of the newborn IGR rats. Lung phospholipid content was apparently unaffected by the intrauterine nutritional deprivation in the IGRs (Table 1), but the DSPC content was decreased by $11-12 \%$ in the IGR pups lungs $(p<0.05)$ as was the DSPC/PL ratio. In comparing the lung structure in the two groups of newborns (Table 2), we found that the IGRs had approximately a $25 \%$ decrease in lung volume $\left(\mathrm{V}_{\mathrm{L}}\right)$ which was matched by an approximately $25 \%$ decrease in lung ISA for respiratory exchange. When the morphometric values were normalized for the difference in body size between the IGR and control pups ( $\mathrm{V}_{\mathrm{L}^{-}}$and ISA-specific), a slight but significant reduction in the normal surface area for respiratory exchange was found in the IGR lungs at birth (Table 2).

We additionally looked at the comparative effects of hyperoxic exposure on lung biochemical parameters including the responses of the protective antioxidant enzyme systems, and also at the effects of high $\mathrm{O}_{2}$ on the structure of the growing lung in both neonatal pup groups.

The data in Table 3 reflects the anticipated inhibitory effect of hyperoxia on lung biosynthetic processes, with depressions of lung protein, DNA, and RNA in both groups of rat pups to essentially an equivalent degree. The results listed in Table 3 also show that the pulmonary antioxidant enzyme response to hyperoxia in the IGRs was no different than the control neonates' responses, with equivalent significant elevations of SOD $(\sim 50 \%)$, CAT $(\sim 75 \%)$, GP $(\sim 140 \%)$, and G-6-PD $(\sim 90 \%)$ activities. The morphometric data (Table 4 ) indicate marked $\mathrm{O}_{2}$-induced decreases in (specific) lung volume and ISA, but the inhibitory effects of $\mathrm{O}_{2}$ on the growing lung were comparable in both neonatal pup groups.

Table 1. Lung biochemical parameters in newborn normal and IGR rat pups*

\begin{tabular}{ccccc}
\hline & \multicolumn{4}{c}{ Antioxidant enzymes $\dagger$} \\
\cline { 2 - 5 } Group & SOD & CAT & GP & G-6-PD \\
\hline $\begin{array}{c}\text { Normal } \\
\text { newborns }\end{array}$ & $57.6 \pm 3.9$ & $548 \pm 42$ & $2.49 \pm 0.30$ & $0.990 \pm 0.087$ \\
$\begin{array}{c}\text { IGR new- } \\
\text { borns }\end{array}$ & $59.4 \pm 3.9$ & $517 \pm 59$ & $2.02 \pm 0.26 \ddagger$ & $0.846 \pm 0.069 \ddagger$ \\
& & & &
\end{tabular}

\begin{tabular}{cccc} 
& $\begin{array}{c}\text { PL }(\mu \mathrm{g} / \mathrm{mg} \\
\text { protein })\end{array}$ & $\begin{array}{c}\text { DSPC } \\
(\mu \mathrm{g} / \mathrm{mg} \\
\text { protein) }\end{array}$ & DSPC/PL (\%) \\
\cline { 2 - 4 } & $194 \pm 17$ & $53.2 \pm 6.8$ & \\
$\begin{array}{c}\text { Normal } \\
\text { newborns }\end{array}$ & $196 \pm 16$ & $47.2 \pm 5.8 \ddagger$ & $24.0 \pm 2.1 \ddagger$ \\
$\begin{array}{c}\text { IGR new- } \\
\text { borns }\end{array}$ & & & \\
\hline
\end{tabular}

* Values for newborn pups from normally fed pregnant rats and from pregnant rats restricted to $25 \%$ of normal food intake throughout second half of pregnancy. Values $=$ mean \pm 1 SD for nine to 12 samples per group (three experiments).

$\dagger$ Lung SOD (U/mg DNA), CAT (IU/mg DNA), GP ( $\mu \mathrm{mol}$ NADPH oxid/min/mg DNA), and G-6-PD ( $\mu \mathrm{mol} \mathrm{NADP} \mathrm{red} / \mathrm{min} / \mathrm{mg} \mathrm{DNA}$ ) activities.

$\ddagger p<0.05$ for IGRs compared to normal newborns.

\section{DISCUSSION}

Animal model for IGR. In humans, a variety of untoward factors have been associated with the delivery of low birth weight, small for gestational age infants $(1,2,20,21)$. The more common conditions include medical complications of pregnancy such as toxemia, chronic hypertension, continuous medication with corticosteroids and other growth-retardant drugs, and excess cigarette smoking, teen-age pregnancy, and perhaps exposure to environmental toxins. The common denominator in all these conditions, and in experimental IGR, is believed to be compromised blood flow to the fetal-placental unit with consequent depression of nutrient supply to the developing fetus $(4,5,20$ 22). Experimentally, unilateral ligation of the uterine artery, chronic exposure of the pregnant animal to hypoxia, partial nephrectomy, and dietary manipulations have all been used to compromise the nutrient (and $\mathrm{O}_{2}$ ) supply to the fetuses (20-23). Our choice of IGR dietary protocol, supplying approximately $25 \%$ of the normal food intake during the 2 nd half of pregnancy, was successful in producing a rather consistent $20-30 \%$ reduction in newborn birth weight without producing the excess fetal wastage which is a problem with the surgical and hypoxia models (23).

Effect of nutrition on pulmonary $\mathrm{O}_{2}$ toxicity. Recently, much overdue attention in the literature is being focused on the influence of altered nutrition on $\mathrm{O}_{2}$ tolerance/susceptibility; nutritional support of $\mathrm{O}_{2}$-requiring neonates has been criticized as woefully inadequate, due perhaps to the concentration of time and attention required for ideal respiratory care, and the problems involved in use of the parenteral route for nutrition. Its now been shown in both experimental and clinical studies that failure to provide adequate caloric maintenance may have serious aggravating effects on $\mathrm{O}_{2}$-induced lung damage $(5,24-26)$. We have recently demonstrated in normal newborn rats that hypocaloric undernutrition will consistently reduce the tolerance of

Table 3. Lung biochemical parameters in air and $\mathrm{O}_{2}$-exposed normal and IGR rat pups*

\begin{tabular}{lcccc}
\hline Group & $\begin{array}{c}\text { Lung wt } \\
(\mathrm{mg})\end{array}$ & $\begin{array}{c}\text { Lung protein } \\
(\mathrm{mg})\end{array}$ & $\begin{array}{c}\text { Lung DNA } \\
(\mathrm{mg})\end{array}$ & $\begin{array}{c}\text { Lung RNA } \\
(\mathrm{mg})\end{array}$ \\
\hline Normals in air & $153 \pm 11$ & $21.5 \pm 1.3$ & $3.38 \pm 0.28$ & $1.61 \pm 0.15$ \\
Normals in $\mathrm{O}_{2}$ & $145 \pm 18$ & $19.1 \pm 2.8$ & $2.32 \pm 0.62 \dagger$ & $1.29 \pm 0.17 \dagger$ \\
& & & & \\
IGRs in air & $106 \pm 16$ & $16.2 \pm 3.1$ & $2.42 \pm 0.22$ & $1.23 \pm 0.15$ \\
IGRs in $\mathrm{O}_{2}$ & $109 \pm 10$ & $13.9 \pm 0.8$ & $1.63 \pm 0.29 \dagger 0.99 \pm 0.09 \dagger$
\end{tabular}

Antioxidant enzymes

\begin{tabular}{llll}
\hline SOD & CAT & GP & G-6-PD \\
\hline
\end{tabular}

Normals in air $61.5 \pm 3.8 \quad 453 \pm 29 \quad 2.69 \pm 0.31 \quad 1.15 \pm 0.12$ Normals in $\mathrm{O}_{2} \quad 94.3 \pm 22.5 \dagger 837 \pm 136 \dagger 6.48 \pm 1.98 \dagger 2.13 \pm 0.44 \dagger$

IGRs in air $\quad 62.8 \pm 10.0 \quad 493 \pm 84 \quad 2.41 \pm 0.52 \quad 1.11 \pm 0.11$

IGRs in $\mathrm{O}_{2} \quad 93.8 \pm 13.5 \dagger 825 \pm 204 \dagger 5.61 \pm 1.17 \dagger 2.15 \pm 0.42 \dagger$

* Values for pups exposed to $>95 \% \mathrm{O}_{2}$ or $21 \% \mathrm{O}_{2}$ from birth to age 5 days; mean \pm 1 SD for six to eight animals per group.

$\dagger p<0.01$ for comparisons of $\mathrm{O}_{2}$-exposed to air-exposed pups for each subgroup.

Table 2. Lung morphometry in newborn normal and IGR rat pups*

\begin{tabular}{lcccccc}
\hline \multicolumn{1}{c}{ Group } & $\mathrm{V}_{\mathrm{L}}(\mathrm{ml})$ & $\begin{array}{c}\mathrm{V}_{\mathrm{L}} \text {-specific } \\
(\mathrm{ml} / 100 \mathrm{~g} \text { body wt) }\end{array}$ & $\%$ Air space & $\mathrm{L}_{\mathrm{m}}(\mu \mathrm{m})$ & $\begin{array}{c}\text { ISA-specific } \\
\text { ISA }\left(\mathrm{cm}^{2}\right)\end{array}$ & \begin{tabular}{c}
$\left(\mathrm{cm}^{2} / 100 \mathrm{~g} \mathrm{body} \mathrm{wt}\right)$ \\
\hline Normal newborns
\end{tabular} \\
IGR newborns & $0.256 \pm 0.021$ & $4.20 \pm 0.36$ & $69.6 \pm 1.5$ & $53.8 \pm 2.0$ & $18.1 \pm 1.6$ & $300 \pm 22$ \\
& $0.195 \pm 0.018$ & $3.93 \pm 0.33$ & $68.6 \pm 2.3$ & $54.9 \pm 2.4$ & $13.8 \pm 1.2$ & $278 \pm 21$ \\
& $p<0.005$ & $\mathrm{NS}$ & $\mathrm{NS}$ & $\mathrm{NS}$ & $p<0.001$ & $p<0.025$ \\
\hline
\end{tabular}

* Values for newborns; mean $\pm 1 \mathrm{SD}$ for three lung sections ( $30 \mathrm{hpf} / \mathrm{section})$ from five animals per group. 
Table 4. Lung morphometry in $\mathrm{O}_{2}$-exposed normal and IGR rat pups*

\begin{tabular}{|c|c|c|c|c|c|c|}
\hline Group & $\mathrm{V}_{\mathrm{L}}(\mathrm{ml})$ & $\begin{array}{c}V_{\mathrm{L}} \text {-specific } \\
\text { (ml/100 g body wt) }\end{array}$ & $\%$ Air space & $\mathrm{L}_{\mathrm{m}}(\mu \mathrm{m})$ & ISA $\left(\mathrm{cm}^{2}\right)$ & $\begin{array}{c}\text { ISA-specific } \\
\left(\mathrm{cm}^{2} / 100 \mathrm{~g} \text { body wt }\right)\end{array}$ \\
\hline Normal air & $0.63 \pm 0.04$ & $5.32 \pm 0.08$ & $72.8 \pm 0.2$ & $34.8 \pm 3.0$ & $72.9 \pm 1.9$ & $608 \pm 21$ \\
\hline Normal $\mathrm{O}_{2}$ & $0.55 \pm 0.05$ & $4.51 \pm 0.28 \dagger$ & $78.9 \pm 1.3 \dagger$ & $46.8 \pm 4.8 \dagger$ & $47.4 \pm 8.9 \dagger$ & $390 \pm 61 \uparrow$ \\
\hline IGR air & $0.50 \pm 0.07$ & $5.54 \pm 0.38$ & $73.5 \pm 0.9$ & $41.0 \pm 1.7$ & $53.0 \pm 1.1$ & $555 \pm 22$ \\
\hline IGR $\mathrm{O}_{2}$ & $0.39 \pm 0.01 \dagger$ & $4.53 \pm 0.05 \dagger$ & $78.5 \pm 0.1 \dagger$ & $48.4 \pm 3.9 \dagger$ & $31.4 \pm 5.1 \dagger$ & $354 \pm 105 \dagger$ \\
\hline
\end{tabular}

* Values for pups exposed to $>95 \% \mathrm{O}_{2}$ or $21 \% \mathrm{O}_{2}$ for 5 days; mean $\pm 1 \mathrm{SD}$ for three lung sections ( $30 \mathrm{hpf} /$ section) from three animals per group. $\dagger p<0.05$ for comparison of air and $\mathrm{O}_{2}$-exposed pups from same subgroups.

the pups to hyperoxic exposure during the 1st wk of life (mortality increased from $27 \%$ in normally nourished rat pups to $56 \%$ in the undernourished group) (5). Postnatal undernutrition also has additive effects with hyperoxia in inhibiting lung growth potential and may further compromise the lung's ability to repair $\mathrm{O}_{2}$ induced damage $(5,25-28)$. Clinically its been observed that respiratory-distressed infants who were provided with more normocaloric parenteral nutrition had a much better outcome than a control group of similarly sick infants on $\mathrm{O}_{2}$ therapy whose nutritional support consisted only of sugar and electrolyte solutions early in life (24).

Whether the prolonged stress of prenatal undernutrition might also negatively influence the ability of the newborn to withstand toxic high $\mathrm{O}_{2}$ challenge, has not (to our knowledge) been previously investigated. Since a proportion of the lower birth weight population which are considered especially prone to suffer serious $\mathrm{O}_{2}$-associated lung damage (BPD) are likely to have developed in a compromised in utero environment, the influence of prenatal nutritional deficiency and growth retardation on the course of these $\mathrm{O}_{2}$-exposed neonates deserves experimental study.

Reasons for decreased hyperoxic tolerance of IGR rat pups. We consistently found that the IGR rat pups produced by the animal model we used were more susceptible to $\mathrm{O}_{2}$-induced lethality, with a significantly reduced $\mathrm{LT}_{50}$ in hyperoxia of 7.2 days compared to 10.0 days for the rat pups normally nourished in utero. We investigated several possible mechanisms to try to define the reason(s) for the impaired $\mathrm{O}_{2}$ tolerance in the IGR pups. We found the lung surfactant (DSPC) content to be slightly but significantly depressed in the IGRs at birth. Surfactant production had apparently been delayed in maturation since gestational day 21 DSPC values were found to be even more markedly lower in the IGR than in the normally nourished fetal rat lungs [values for 1-day premature pups $=23.6 \pm 2.7$ (IGRs) versus $37.1 \pm 7.0 \mu \mathrm{g} / \mathrm{mg}$ protein (normal controls), $n=8, p<0.01$ ]. Since $\mathrm{O}_{2}$ exposure tends to inhibit surfactant synthesis $(29,30)$, if the $\mathrm{O}_{2}$-exposed IGRs were less able to compensate for the effect of hyperoxia by increasing surfactant production rates as readily as normally nourished pups, this could compromise their lung function and perhaps contribute to their diminished $\mathrm{O}_{2}$ tolerance.

The lung's primary defensive system against $\mathrm{O}_{2}$ toxicity - the antioxidant enzymes-did show differences in the two groups of newborns, with significantly reduced lung GP and G-6-PD activities in the IGRs. GP is believed to play the key role in the lung in detoxifying cytotoxic $\mathrm{H}_{2} \mathrm{O}_{2}$ and also, together with G-6-PD and the enzyme glutathione reductase, is important for its role in detoxifying lipid peroxides produced by the interaction of reactive $\mathrm{O}_{2}$ species and unsaturated lipids in the cell $(31,32)$. These enzyme deficits could have contributed to the early production of $\mathrm{O}_{2}$-induced lung injury in the IGR pups. Although by 5 days of $\mathrm{O}_{2}$ exposure the IGR pups had responded appropriately to hyperoxia with adaptive increases of all the antioxidant enzymes (Table 3), nonetheless, even transient early depression of the glutathione detoxification system has recently been reported to seriously compromise tolerance to prolonged $\mathrm{O}_{2}$ exposure (33).

Except for the changes we found in lung GP and G-6-PD levels at birth, the moderate decrease in lung surfactant (DSPC) content, and the morphometric evidence for reduced specific ISA at birth, we at this point have no clear-cut explanation for the decreased $\mathrm{O}_{2}$ tolerance of the IGR pups. The cyanotic appearance, gasping respirations, and nasal frothing of the pups just prior to their deaths, together with the grossly swollen appearance of the lungs clearly indicated to us a pulmonary cause for their demise. In examining the literature for other parameters that are different in normally nourished and growthretarded newborns we have found the following data which could partially explain the accelerated pulmonary $\mathrm{O}_{2}$ toxicity in the IGR pups: (1) small for gestational age newborns are reportedly in a relatively hypermetabolic state with increased rates of $\mathrm{O}_{2}$ consumption-experimentally produced hypermetabolism with increased $\mathrm{O}_{2}$ consumption results in greater $\mathrm{O}_{2}$-free radical production and an acceleration of $\mathrm{O}_{2}$ toxicity $(30,32,34,35) ;(2)$ IGR rat pups reportedly have depressed capacity for ATP synthesis (36), and depressed capacity for DNA synthesis and cell proliferation $(37,38)$-both of these characteristics could be important in depressing the repair response to ongoing $\mathrm{O}_{2}$ induced lung cell injury; and finally, (3) purely postnatal adaptations in other organs (brain myelination) have been found to be altered by malnutrition during the prenatal period only (39).

Further studies will obviously need to be done to understand why prenatal malnutrition appears to have as marked a detrimental effect on tolerance/susceptibility to pulmonary $\mathrm{O}_{2}$ toxicity as postnatal nutritional deficiency is now known to have.

Acknowledgment. The authors thank Mrs. Ondina GarciaPons for her assistance with the manuscript preparation.

\section{REFERENCES}

1. Miller HC 1981 Intrauterine growth retardation. Am J Dis Child 135:944-948

2. Hobbins JC, Berkowitz RL, Grannum PAT 1978 Diagnosis and antepartum management of intrauterine growth retardation. J Reprod Med 21:319-325

3. Tooley WH 1979 Epidemiology of bronchopulmonary dysplasia. J Pediatr 95:851-855

4. Smith DW, Stevenson DK, Sunshine P, Northway W, Ariagno RL 1983 Predominance of bronchopulmonary dysplasia (BPD) in infants $<1500 \mathrm{gm}$ at birth. Am Rev Respir Dis 127:212

5. Frank L, Groseclose E 1982 Oxygen toxicity in newborn rats: the adverse effects of undernutrition. J Appl Physiol 53:1248-1255

6. McCord JM, Fridovich I 1969 Superoxide dismutase: an enzyme function for erythrocuprein (hemocuprein). J Biol Chem 244:6049-6055

7. Richards GM 1974 Modifications of the diphenylamine reaction giving increased sensitivity and simplicity in the estimation of DNA. Anal Biochem 57:369-376

8. Schneider WC 1956 Determination of nucleic acids in tissue by pentose analysis. In: Colowick SP, Kaplan NO (eds) Methods in Enzymology, Vol 3. Academic Press Inc, New York, pp 680-684

9. Schacterle RE, Pollack RL 1973 A simplified method for the quantitative assay of small amounts of protein in biological material. Anal Biochem 51:654655

10. Holmes RS, Masters CJ 1970 Epigenetic interconversion of the multiple forms of mouse liver catalase. FEBS Lett 11:45-48

12. Paglia DE, Valentine WN 1967 Studies on the quantitative and qualitative characterization of erythrocyte glutathione peroxidase. J Lab Clin Med 70:158-169

12. Langdon RG 1966 Glucose-6-phosphate dehydrogenase from erythrocytes. In: Colowick SP, Kaplan NO (eds) Methods in Enzymology. Academic Press Inc, New York, pp 126-131

13. Bligh EF, Dyer WJ 1959 A rapid method of total lipid extraction and purifi- 
cation. Can J Biochem Physiol 37:911-917

14. Morrison WR 1964 A fast, simple and reliable method for the micro-determination of phosphorus in biological materials. Anal Biochem 11:218-224

15. Mason RJ, Nellenbogen J, Clements JA 1976 Isolation of disaturated phosphatidylcholine with osmium tetroxide. J Lipid Res 17:281-284

16. Weibel ER 1963 In: Morphometry of Human Lung. Academic Press Inc, New York, pp 1-39

17. Scherle W 1970 A simple method for volumetry of organs in quantitative stereology. Mikroskopie 26:57-60

18. Steel RGD, Torrie JH 1960 Principles and Procedures of Statistics. McGraw Hill, New York, pp 67-98, 366-387

19. Litchfield JT Jr, Wilcoxon F 1949 A simplified method of evaluating doseeffect experiments. J Pharmacol Exp Ther 96:99-113

20. Miller HC 1983 A model for studying the pathogenesis and incidence of lowbirth-weight infants. Am J Dis Child 137:323-327

21. Evans MI, Lin C-C 1984 Retarded fetal growth. In: Lin C-C, Evans MI (eds) Intrauterine Growth Retardation. McGraw Hill, New York, pp 55-77

22. Mulay S, Browne CA, Varma DR, Solomon S 1980 Placental hormones, nutrition, and fetal development. Fed Proc 39:261-265

23. Van Geijn GP, Kaylor WM Jr, Nicola KR, Zuspan FP 1980 Induction of severe intrauterine growth retardation in the Sprague-Dawley rat. Am J Obstet Gynecol 137:43-47

24. Gunn T, Reaman G, Outerbridge EW, Colle E 1978 Peripheral total parenteral nutrition for premature infants with the respiratory distress syndrome: a controlled study. J Pediatr 92:608-613

25. Roberts RJ 1978 Implications of nutrition in oxygen-related pulmonary disease in the human premature infant. Adv Pharmacol Ther 8:53-64

26. Hackney JJ, Evans MJ, Bils RF, Spier CE, Lones MP 1977 Effects of oxygen at high conentrations and food deprivation on cell division in lung alveoli of mice. Exp Mol Pathol 26:350-358
27. Polgar G, Antagnoli W, Ferrigan LW, Martin EA, Gregg WP 1966 The effect of chronic exposure to $100 \%$ oxygen in newborn mice. Am J Med Sci $112: 580-587$

28. Massaro D, Massaro GD 1978 Biochemical and anatomical adaptation of the lung to oxygen-induced injury. Fed Proc 37:2485-2488

29. Gross NJ, Smith DM 1981 Impaired surfactant phospholipid metabolism in hyperoxic mouse lungs. J Appl Physiol 51:1198-1203

30. Huber RL, Drath DB 1981 Pulmonary oxygen toxicity. In: Gilbert DL (ed) Oxygen and Living Processes. An Interdisciplinary Approach. SpringerVerlag, New York, pp 273-324

31. Frank L, Massaro D 1980 Oxygen toxicity. Am J Med 60:117-126

32. Freeman BA, Crapo JD 1982 Biology of disease. Free radicals and tissue injury. Lab Invest 47:412-426

33. Deneke SM, Fanburg BL 1983 Effect of transient decrease in glutathione on rat oxygen toxicity. Am Rev Respir Dis 127:284

34. Scopes JW, Ahmed I 1966 Minimal rates of oxygen consumption in sick and premature newborn infants. Arch Dis Child 41:407-416

35. Sauer PJJ, Dane HJ, Visser HKA 1984 Longitudinal studies on metabolic rate, heat loss, and energy cost of growth in low birth weight infants. Pediatr Res 18:254-259

36. Hawrylewicz EJ, Kissane JQ, Blair WH, Heppner CA 1973 Effect of maternal protein malnutrition on neonatal lung development and mitochondrial function. Nutr Rep Int 7:253-269

37. Roux JM 1971 Decrease in the rate of DNA synthesis in newborn rats with intrauterine growth retardation. Biol Neonate 18:463-467

38. Faridy EE 1975 Effect of maternal malnutrition on surface activity of fetal lungs in rats. J Appl Physiol 39:535-540

39. Morand O, Chanez C, Masson M, Dumont O, Flexor MA, Baumann N, Bourre JM 1982 Alteration in fatty acid composition of neurons, astrocytes, oligodendrocytes, myelin and synaptosomes in intrauterine malnutrition in rat. Ann Nutr Metab 26:111-120

\title{
Composition and Surface Activity of Normal and Phosphatidylglycerol-Deficient Lung Surfactant
}

\author{
MIKKO HALLMAN, GORAN ENHORNING, AND FRED POSSMAYER \\ Department of Pediatrics, University of Helsinki, 00290 Helsinki 29, Finland, and University of California, San \\ Diego, La Jolla, California 92093 [M.H.], Departments of Obstetrics and Gynaecology, University of Toronto, \\ Toronto, Ontario, Canada MST 2S8 [G.E.], and University of Western Ontario, \\ London, Ontario, Canada N6A 5 A5 [F.P.]
}

\begin{abstract}
The possibility that pulmonary surfactant, characterized by a phosphatidylglycerol deficiency, as in early fetal life, might have inferior surface properties was evaluated. We obtained this specific surfactant from adult rabbits by withholding glucose and giving them an excess of myoinositol by mouth and intravenously. Controls were given a similar quantity of glucose. The myoinositol resulted in a drastic reduction of surfactant phosphatidylglycerol, from 7.2 to $0.3 \%$ of phospholipids, and a corresponding increase in phosphatidylinositol from 4.8 to $11.3 \%$. In addition, the myoinositol treatment increased the myoinositol that was disaturated from 18.5 to $27.3 \%(p<0.05)$. The corresponding figures for disaturated phosphatidyl-
\end{abstract}

Received June 12, 1984; accepted October 24, 1984.

Requests for reprints should be addressed to Mikko Hallman, M.D., Children's Hospital, University of Helsinki, Stenbäckinkatu 11, 00290 Helsinki 29, Finland.

Supported by grants from the Finnish Academy, the Juselius Foundation (M.H.), a United States Public Health Service Grant (HD-04380 to Louis Gluck), and the Medical Research Council of Canada (Grant MT-4497 to G.E.). choline were 56.0 and $60.5 \%$, respectively (NS). The myoinositol treatment for $\mathbf{4}$ days increased the pool size of alveolar surfactant by $32 \%(p<0.01)$. The surface activity was studied with modified Wilhelmy balance and the pulsating bubble surfactometer. Surfactant containing phosphatidylinositol rather than phosphatidylglycerol was not inferior, as compared to surfactant that contained phosphatidylglycerol (minimum surface tension: 2.0 versus 2.2 $\mathrm{mN} \cdot \mathrm{m}^{-1}$; collapse rate at $10 \mathrm{nM} \cdot \mathrm{m}^{-1}: 1.85$ versus 1.95 $\mathrm{min}^{-1}$; rate of adsorption from subphase to surface: 32 versus $35 \mathrm{mN} \cdot \mathrm{m}^{-1} \cdot 30 \mathrm{~s}^{-1}$ ), nor was there a difference in the ability of the two surfactants to improve lung stability of 27-day-old rabbit fetuses (air retention at $35 \mathrm{~cm} \mathrm{H}_{2} \mathrm{O}$ : 1.8 versus $1.8 \mathrm{ml} / 30 \mathrm{~g}$; air retention at $0 \mathrm{~cm} \mathrm{H} \mathrm{H}_{2} 0: 0.8$ versus $0.9 \mathrm{ml} / 30 \mathrm{~g})$. We conclude that phosphatidylinositol surfactant does not have inferior surface properties. Myoinositol affects not only the acidic surfactant phospholipids but also increases the pool size of surfactant by an as yet unknown mechanism. (Pediatr Res 19: 286-292, 1985) 